University at Buffalo School of Law

Digital Commons @ University at Buffalo School of Law

\title{
Hidden in Plain View: Legal Geography from a Visual Perspective
}

Irus Braverman

University at Buffalo School of Law

Follow this and additional works at: https://digitalcommons.law.buffalo.edu/journal_articles

Part of the Geography Commons, and the Law Commons

\section{Recommended Citation}

Irus Braverman, Hidden in Plain View: Legal Geography from a Visual Perspective, 7 Law, Culture \& Human. 173 (2010).

Available at: https://digitalcommons.law.buffalo.edu/journal_articles/328

Irus Braverman, Hidden in Plain View: Legal Geography from a Visual Perspective, Journal Title (Journal of Law, Culture, and the Humanities 7:2) pp. 173-186 . Copyright (C) 2011 SAGE Publications. Reprinted by permission of SAGE Publications.

\section{IN COPYRIGHT}

This Article is brought to you for free and open access by the Faculty Scholarship at Digital Commons @ University at Buffalo School of Law. It has been accepted for inclusion in Journal Articles by an authorized administrator of Digital Commons @ University at Buffalo School of Law. For more information, please contact lawscholar@buffalo.edu. 


\section{Hidden in Plain View: Legal Geography from a Visual Perspective}

Irus Braverman, Associate Professor of Law

University at Buffalo, SUNY

Published in (2011) Journal of Law, Culture, and the Humanities 7(2):

173-186 (special issue on Law and Geography) 
Abstract: Law, with a capital "L" at least, is not particularly fond of hiding itself. In order to be effective, law must be asserted in the world; it must be acknowledged; and, most importantly, it must be visually seen. Why, then, would law hide itself in space? And, perhaps more importantly, how would it do so? And why would such hidden places of law be of importance to us? This paper explores the dual project of seeing and concealing within the context of legal geography. It examines how law sees the physical landscape and how it is seen from a spatial perspective. It also asks who does the legal seeing, who and what are being seen by law, and then who and what are rendered invisible in these geolegal sites. In addition, it considers how law's particular way of seeing landscape translates into the making of this space. Finally, and interrelated to all the above, it shows how both the visibility and, perhaps more importantly, the invisibility of law in space are strongly aligned with arrangements of power. The article presents two examples of visible invisibles: tree landscapes in Israel/Palestine and the properties of seeing the natural landscape through human and nonhuman inspection, and through aerial photos in particular; and border crossings and the properties of seeing in motion through the physical design of the border, and through sensor machines in particular.

"To care about one sees in the world leads to mobilizing one's creative powers." Richard Sennett 1990, xiv ${ }^{1}$

\section{Prologue: Visualizing Law}

Law, with a capital "L" at least, ${ }^{2}$ is not particularly fond of hiding itself. In order to be effective, law must be asserted in the world; it must be acknowledged; and, most importantly, it must be visually seen. Why, then, would law hide itself in space? How would it do so? And why are such hidden places of law important to us? This paper explores the dual project of seeing and concealing within the context of legal geography. It examines how law sees and how it is seen from a spatial perspective. It also asks who does the legal seeing, who and what are being seen by law, and then who and what are rendered invisible in these geolegal sites. In addition, it considers how law's particular way of seeing translates into the making of this space. Finally, and interrelated to all the above, it shows how both the visibility and, perhaps more importantly, the invisibility of law in space are strongly aligned with arrangements of power.

That the modern project is dominated by vision, or "ocularcentric,"3 has been explained in many ways, physiological as well as cultural and historical. Scientists have

\footnotetext{
${ }^{1}$ Richard Sennett, The Conscience of the Eye (Alfred Knopf, 1990).

${ }^{2}$ The examples of law's visual projects provided herein are mostly about state law. This does not mean that it is only state vision that matters in legal geographies. On an exploration of the project of seeing within a non-state oriented setting, see Irus Braverman, "The Invisible Side of Zoos: 'Soft Law' in Animal Management" (forthcoming, 2010).

${ }^{3}$ See, e.g., John Berger, Ways of Seeing (Penguin Classics, 2008); Patrick Fuery and Kelli Fuery, Visual Cultures and Critical Theory (Oxford University Press, 2003); Martin Jay, Downcast Eyes: The

Denigration of Vision in Twentieth-Century French Thought (Berkeley: University of California Press,
} 
argued, for example, that man's ancestor was forced to take to the trees, and that arboreal life called for keen vision and decreased dependence on smell. Biologists also maintain that the eye can distinguish between some 500 levels of light and dark and between over one million combinations of color. ${ }^{4}$

It would only seem natural, then, that seeing would assume supremacy over the other senses in legal settings as well. But in certain legal geographies this supremacy is complicated by the role of language. Indeed, for most legal practitioners, language is still the primary medium of translation between the world and its legal representations. The orally centered courtroom requires that language be codified into written and unwritten rules of speech and conduct. Text, rather than images or visions, ${ }^{5}$ is thus the center of legal attention. No wonder that justice is said to be blind.

Yet the courtroom is also a theatre. ${ }^{6}$ In the courtroom, things are not only relayed, but also shown to compel belief. ${ }^{7}$ Vision is central: it manifests in the importance of eye witnessing by lay persons as well as virtual witnessing by experts; in the increased role of forensic science; and in a range of legal doctrines and distinctions, such as the legal distinction between private and public. What constitutes someone's home? Can the police seize drugs placed in plain view? These definitions are based primarily on various aspects of sight and vision. Visualization, no less than verbalization, is thus central for establishing facts in the legal setting. Some would even suggest that the ability to

1993); Martin Jay, "Scopic Regimes of Modernity," in Hal Foster, ed., Vision and Visuality (Seattle: Bay Press, 1988), pp. 3-23.

${ }^{4}$ Jay, Downcast Eyes, pp. 5-6.

${ }^{5}$ Obviously, this distinction is somewhat simplistic as the text itself is an image, and images are also texts.

${ }^{6}$ The term "theatre" shares the same root as the word "theory," which means: to look at attentively, to behold. See Merriam Webster Dictionary online, at http://www merriam-webster.com/dictionary/theatre (visited June 1, 2009).

${ }^{7}$ Sheila Jasanoff, "The Eye of Everyman: Witnessing DNA in the Simpson Trial," Social Studies of Science, 28(5/6) (Oct. 1998) pp. 713-740. 
visualize something internally is a prerequisite to the ability to describe it verbally, thereby rendering the linguistic process as subordinate to the visual senses. ${ }^{8}$

Vision and visuality are not only central to the legal geographies of the courtroom. This article focuses on two examples from my work that explore the ideological properties of seeing and concealing in the context of two other legal geographies: the natural tree landscapes of Israel/Palestine and Israel's border crossing with the occupied West Bank. These two settings, although quite different from one another, demonstrate the dominance of a scopic perspective, one that is characterized by a linear, rational, a-historic, unitary, and disembodied point of view, commonly referred to as a Cartesian perspective. ${ }^{9}$

Beyond presenting acute examples for the hegemonic, yet never exclusive, perspectives through which legal geographies are rendered visible, the two sites studied here also share in common the disciplinary function of the panoptic gaze. They bring into sharper focus the importance of visibility in making the project of law invisible. Additionally, these sites highlight the work that nonhuman technologies (here, aerial photos and sensor machines) in various legal geographies do to conceal power dynamics. Finally, the two sites highlight the imbrication, and even the inseparability, of space and time. As much as it this interconnection is obvious, studies in Legal Geography rarely devote much attention to it, instead focusing on space as if it alone matters.

The visual regime enacted through space-time typifies what I find to be the most crucial insight of Legal Geography: a "taken-for-grantedness" that physical and legal

\footnotetext{
${ }^{8}$ Jay, Downcast Eyes, p. 8.

9 Jay, Scopic Regimes of Modernity, pp.4-12. See also Charles Goodwin, "Professional Vision," American Anthropologist 96(3) (1994), pp. 606-633; Stephen A. Tyler, "The Vision Quest in the West, or What the Mind's Eye Sees," Journal of Anthropological Research 40(1) (1984), pp. 23-40.; Bruno Latour, "On Technical Mediation- Philosophy, Sociology, Geneology," Common Ground 3(2) (1994), pp. 29-64.
} 
matters lend to each other. Indeed, more than any other "law and..." pairing (e.g. law and economics, law and history, law and society etc.), the pairing of law and geography is about the hidden stuff that lies behind the physical or spatial site. Natural landscapes and built environments, machines and bodies, all seem to exist out there - as empty and static terrains upon which power is exercised - and are less realized as power constructs in themselves. The taken for granted aspects of spatial design, I claim here, render it a useful technology for promoting ideological projects. It is through their enactment in space that technologies of power are made hidden. Their enhanced visibility, in other words, is precisely that which renders spatial technologies invisible.

\section{Tree Landscapes in the Occupied West Bank: Seeing from a Bird's Eye View}

\section{A. Seeing through Tree Landscapes}

I begin the exploration into the power of visualization and its close ties with geolegalities by alluding to my own work on natural ${ }^{10}$ landscapes. ${ }^{11}$ In Planted Flags: Trees, Land, and Law in Israel/Palestine, ${ }^{12}$ I explore the project of treescaping the natural landscape of Israel/Palestine, mainly that performed through the planting and uprooting

\footnotetext{
${ }^{10}$ Both the definitions of and the problems with this term are discussed by Kate Soper, What is Nature: Culture, Politics and the Non-Human (Wiley-Blackwell, 1995); Neil Smith, Uneven Development: Nature, Capital, and the Production of Space (Athens, GA: University of Georgia Press, 2008); David Harvey, Justice, Nature, and the Geography of Difference (Malden, MA: Wiley-Blackwell, 1997); Alexander Wilson, The Culture of Nature: North American Landscape from Disney to the Exxon Valdez (Toronto: Between the Lines, 1991).

${ }^{11}$ The use of the term landscape adds a layer of materiality that is perhaps less apparent in the term by itself. The many definitions of landscape can be posited along a continuum - with the morphological emphasis of landscape on the one hand and the representational understanding of landscape on the other. I largely draw on a definition of landscape as "always both a material form that results from and structures social interaction and an ideological representation dripping with power." See Don Mitchell, Lie of the Land: Migrant Workers and the California Landscape (University of California Press, 1996) pp. 34. By referring to landscape both as a physical environment and as a particular way of seeing a place, this definition combines the material and representational perspectives.

${ }^{12}$ Irus Braverman, Planted Flags: Trees, Land, and Law in Israel/Palestine (Cambridge University Press, forthcoming 2009) (Planted Flags). For an explanation of my use of the term Israel/Palestine see fn. 1 of the introduction.
} 
of two types of trees: the pine as the Zionist tree, on the one hand, and the olive, as the Palestinian tree, on the other hand (see, e.g., Figure 1).
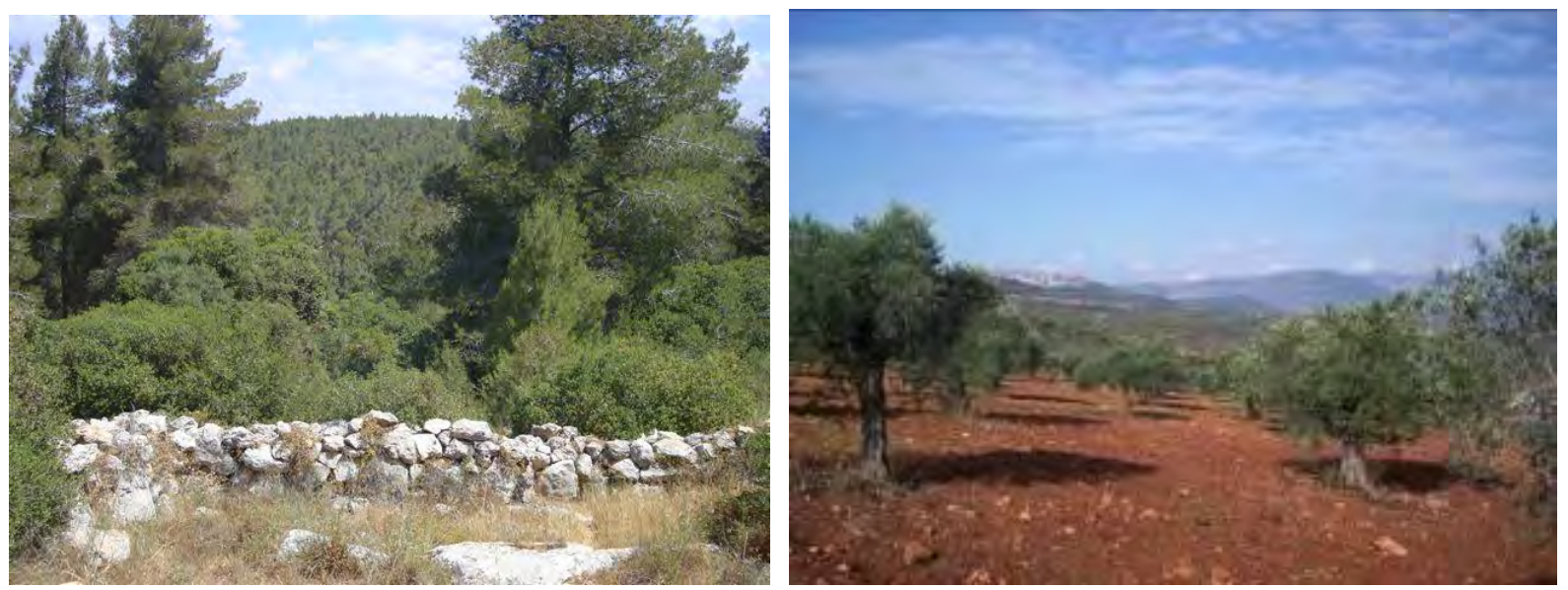

Figure 1: Left, pine forests near Jerusalem; ${ }^{13}$ Right, olive groves in the Galilee ${ }^{14}$

Through the $20^{\text {th }}$ century, Israel has planted some 240 million trees, mostly pines, throughout Israel/Palestine so as to "bloom the desert." Palestinian acts of arson, Hezbollah rockets, and illegal tree chopping for wood, along with fires and infectious diseases, have damaged many of these pines. At the same time, the olive has an increasingly stronger role as a major source of livelihood for Palestinians. Through the years, it has also become a symbol of the Palestinian steadfast resistance to the Israeli occupation. Meanwhile, the State of Israel has been carrying out a massive project of olive uprooting, primarily to enable the construction of a massive Separation Barrier on its borders, and radical Jewish-Israeli settlers have been vandalizing the olive as a way to assert their rights over land.

James Scott's Seeing Like a State ${ }^{15}$ has influenced my thinking about the uses of visibility and invisibility for the project of state governance, and about the incredible

\footnotetext{
${ }^{13}$ Photo by Dan Braverman, January 31, 2009, reprinted with permission.

14 Photo by author, August 2006.

15 James Scott, Seeing Like a State (Yale University Press, 1998).
} 
powers of vision in the context of the Israeli/Palestinian landscape in particular. In his study of scientific forestry in eighteenth century Prussia, Scott highlights the "narrowing of vision" that has been essential for the forest's transformation from a local to a state managed resource. Scott demonstrates, importantly, that maps, metric systems, and other standardized schemes utilized for the management of the scientific forest enable efficient governance by the modern nation-state.

My study of the Israeli/Palestinian tree landscape ${ }^{16}$ demonstrates that the state's desire for a narrowed vision is not the final word in landscape processes, and in this sense the analysis provided herein departs from James Scott's work. ${ }^{17}$ If the state's vision had prevailed exclusively, the Israeli/Palestinian landscape would probably not look too different from that which was envisioned by the state: confined spots of biodiversity amidst massive monocultural pine forests. But this is not the actual lay of the land. Pine forests do not entirely dominate the natural landscape; olive trees, which have traditionally been planted and harvested by Palestinians, are also common in certain parts of the country. The olives and the pines are both soldiers in this national war precisely because the state does not, and cannot, exercise infinite powers over the construction of the natural landscape. ${ }^{18}$

Whereas this exploration promotes a material perspective of legal geographies, it also illustrates that material forms alone cannot explain the intrinsic correlations between ideology and territory. Rather, symbolic and imaginary aspects are also essential to the

\footnotetext{
${ }^{16}$ Braverman, Planted Flags.

${ }^{17}$ For a similar departure, see Fernando Coronil, "Smelling Like a Market," American Historical Review 106(1) (2001), pp. 119-129.

${ }^{18}$ For a more detailed account of the war over the natural landscape in Israel/Palestine see Planted Flags, as well as Irus Braverman, "The Tree is the Enemy Soldier: A Sociolegal Making of War Landscapes in the Occupied West Bank," Law and Society Review 42(3) (Sept. 2008), pp. 449-482.
} 
explanation. ${ }^{19}$ By utilizing the manifest innocence of nature and the seemingly a-temporal properties of landscapes, legal enterprises embody themselves in space, thereby appearing neutral, fixed, and a-temporal. In effect, natural landscapes are convenient ways for making power dynamics seem inevitable and immutable.

\section{B. Inspectors as Legal Geographers}

Why, my work inquires, has the tree, alongside the acts of its planting and uprooting, acquired such a pivotal existence in the Israeli/Palestinian landscape? What is it about this place that lends itself to what I have identified as a "tree fetish" among the peoples of this region and their laws? Obviously, trees are rooted to the land, and in this very immediate physical sense they are also ways of occupying this land, grabbing it, and, most importantly for this context, rendering this occupation legible in the eyes of the state through its laws. The process of land occupation is thus not only material; it is also legal and political. Although various Israeli statutes protect trees, the law that has probably most shaped the natural landscape in Israel/Palestine in the last century is the 1858 Ottoman Land Code. Article 78 of this Code grants land ownership to a long-time cultivator of fruit trees. The flipside of this law is Israel's practice of declaring as state

\footnotetext{
${ }^{19}$ Indeed, my work grapples with the interchangeability and interconnectedness between the material and the discursive. See Planted Flags, as well as Irus Braverman, "A Toilet Inspection," In Outing the Water Closet: Sex, Gender and the Public Restroom, Harvey Molotch and Laura Noren (eds.) (NYU Press, forthcoming, 2009), and Irus Braverman, "Loo Law: The Public Washroom as a Hyper-Regulated Space," Hastings Women's Law Journal 20(1): 45-71 (Winter 2008). For similar discussions of this interconnectedness the Legal Geography literature see David Delaney, "Beyond the Word: Law as a Thing of This World," in Law and Geography eds. Jane Holder and Carolyn Harrison (Oxford, 2003), pp. 67-84, as well as Davina Cooper, Governing Out of Order: Space, Law, and the Politics of Belonging (London: Rivers Oram Press/Pandora Press, 1998) and Eve Darian-Smith, Bridging Divides: The Channel Tunnel and English Legal Identity in the New Europe (Los Angeles, CA: University of California Press, 1999). More generally, see Karen Barad, "Posthumanist Performativity: Toward an Understanding of How Matter Comes to Matter," Signs: Journal of Women in Culture and Society 28(3) (2003), pp. 801-831, and Karen Dale, "Building a Social Materiality: Spatial and Embodied Politics in Organizational Control," Organization 12 (2005), pp. 649-678.
} 
land those lands that have not been cultivated for a sufficient time period as defined by the Code. ${ }^{20}$

Over a century after its inception, Israel still abides by this Ottoman law, especially in the occupied West Bank. State inspectors survey the landscape looking for trees. Based on their tree findings, the inspectors distinguish between cultivated and uncultivated land, declaring the latter as state land. Then, they detect recent tree invasions to this land, usually by olives. Finally, they often uproot these olives and in many cases plant state pine trees instead.

Using their naked eyes, the inspectors determine if a tree is old enough or an orchard dense enough to establish ownership. When the answer is contested, a Land Committee comprised of Israeli lawyers who act as judges decides on the matter. The inspectors are thus the first-level intermediaries between the nation-state and its territory; they perform this mediation through the act of seeing. Inspectors are, in other words, the eyes of the state. Theirs is the official view - and moreover, the only official view - of the landscape. But more and more, this naked eye reading by Israel's human inspectors is being replaced by various scientific technologies, and most prominently by the aerial photograph.

\section{Aerial Photos as a Geolegal Technology}

Although it makes no explicit mention of trees, the legal system practiced in the occupied West Bank sets a clear preference toward cultivation of trees rather than any other form of cultivation. The key factor in making the tree into such a powerful entity in this specific context is the technology of aerial photography. Unlike the eye of the telescope or the microscope, which mostly enhance the natural functions of the human

\footnotetext{
${ }^{20}$ For a more detailed discussion of this process see Braverman, The Tree is the Enemy Soldier.
} 
eye, the gaze of the aerial photo not only records certain data in more detail than the eye can account for, but it is commonly used long after the moment of its inception, thus granting the human eye the ability to see back in time.

More than anything else, the introduction of aerial photos into the legal proceedings that take place in the occupied West Bank has served to reinforce the importance of trees in this context. Western law traditionally considers visual imagery as more direct than words, and "mechanical images that could be touted as nature's self portrait ... as yet more immediate." 21 This particular characteristic of aerial photos has lent them the force of being categorized as objective facts by the legal system practiced in the West Bank rather than as subjective interpretations. In effect, an aerial photo shot 10 years ago has the power to refute or support a Palestinian farmer's claim that he or she has been cultivating their fruit trees for the necessary length of time required by law to establish ownership.

As a sensory technology, however, aerial photos also introduce a set of limitations into legal proceedings. Most basically, the aerial photo translates the landscape from a three, or even four, dimensional space into two dimensions, freezing both space and time onto a flat surface that in turn renders them transferrable. This process sacrifices both the depth and the richness of the visual account. As James Scott has observed, the modern state promotes a narrowing of vision, a synoptic, bird's eye view from a distance that records only that information that is rendered valuable by the state, leaving out the messy stuff that happens on the ground.

\footnotetext{
${ }^{21}$ Lorraine Daston and Peter Galison. “The Image of Objectivity.” Representations 40 (1992), p. 120.
} 
Also, on the immediate physical level, climatic conditions in the region limit the use of aerial photography to the fall and spring seasons. This technical blindness of aerial photos to certain seasonal vegetation brings the discussion back to trees. Mostly because of the tree's fixed, unambiguous, and continual physical presence through the seasons, the technology of aerial photography tends to strongly favor trees. In this sense, the admissibility of aerial photography in Israel's legal proceedings in the West Bank has granted aerial photographs with power not only to see the natural landscape, but also to make it.

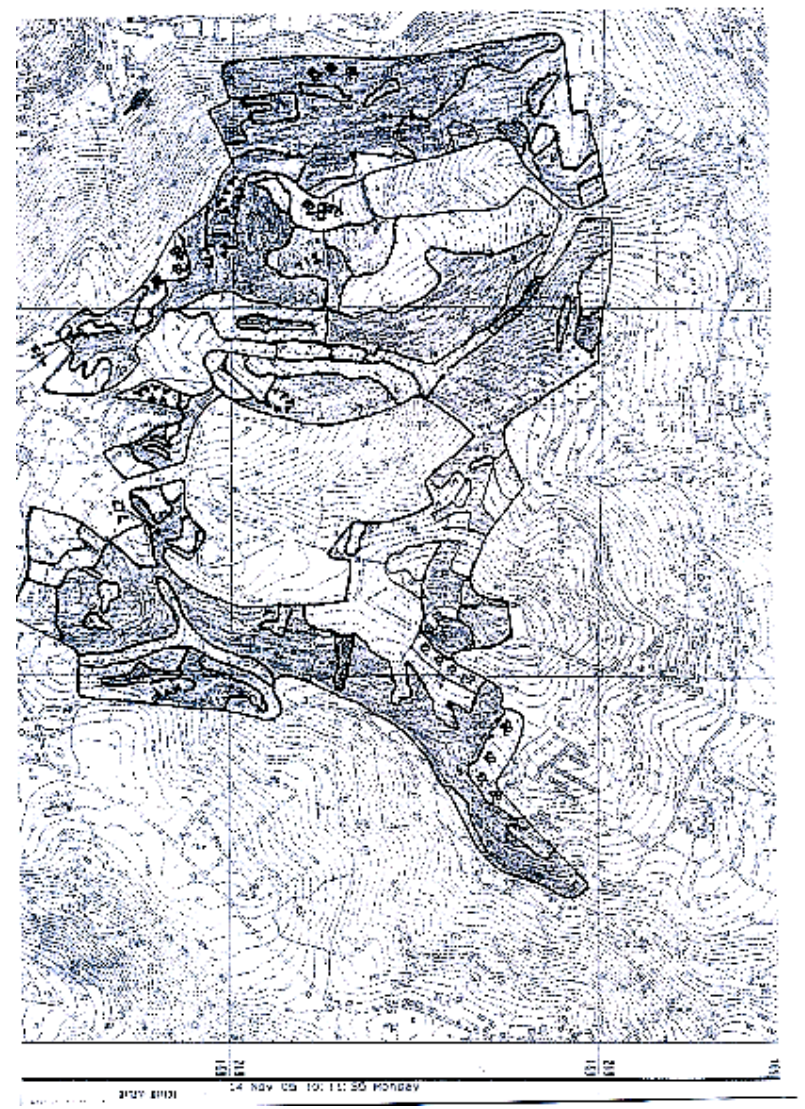

Figure 2: A reproduced aerial photo (originally in color), representing parcel boundaries and single trees (e.g. in the lower right corner); courtesy of Survey of Israel: Agency for Geodesy, Cadastre, Mapping and Geographic Information. 
Malka Offri, the state's expert on aerial photos, further illustrates this point. Offri regards trees as strategic reference points, or, in her words, as "anchors in the landscape." Offri explains, for example, that

There's no detail in the area that escapes our eyes. Every detail in the territory gets a code [...]. That doesn't include humans. [...] You can't really map people. Trees, on the other hand, don't move. People move, but things stay in place... Sometimes I spot goats in the aerial photo. It's amazing to see them there. Of course, I don't mark them into the map, because they move. [I only map] existing things. ${ }^{22}$

Because trees "exist" in an immobile way that does not really change with the seasons, they are the most readable objects in the nonbuilt terrain, consequently serving as central reference points for the aerial photo interpreter. The trees' presence, absence, and relative location are thus central to law-craft. In this sense, the relationship between trees and aerial photos also speaks to the correlation between visibility, fixity, and law. This, perhaps, is why trees, rather than seasonal vegetation and other temporary occupations of land, have been so successful in this setting: as patently legible entities, they are a statement. "See me!", their upright presence screams out to the eyes of state law.

But then again, the state's ability to read time and to interpret space through the perspective of aerial photography is problematic for the same features that are also so intrinsic to the application of this technology: a disregard for things that "do not exist"; namely, human behavior. This blind spot in the aerial photo's vision is as political as it are physical. For example, the photo doesn't tell us who planted the trees, or why trees have not been planted in certain spaces. Moreover, even if the aerial photo was capable of perfectly determining the age of a tree for the purpose of establishing clear legal

${ }^{22}$ Malka Offri, Director of Interpretation Department, Israeli Department of Cartography, interview, Tel Aviv, August 22, 2006. 
categories of cultivation, it would still not determine the identity of the person who planted the tree or that who has cultivated it through the years.

This brings me to the next important point: while by highlighting certain aspects of the landscape (such as trees) the aerial photo makes the landscape legible in the eyes of the state, at the same time it also obscures other aspects of the landscape. The heightened visibility provided by the legal technology, in other words, also promotes various invisibilities. Palestinian advocate Suliman Shahin identifies two distinct problems with the extensive reliance of Israel's military committees on aerial photos. ${ }^{23}$ First, he argues, the high costs involved with their production make aerial photos inaccessible to most Palestinian farmers, thereby reinforcing their basic discrimination. ${ }^{24}$

But even more importantly, Shahin critiques the limited perspective encouraged by the frequent use of aerial photos by Israeli military committees. In particular, he claims that by restricting the discussion to the single question of whether or not the land has been cultivated for a legally defined period of time, aerial photos enable legal committees that operate in the West Bank to ignore the conditions that have prevented Palestinians from cultivating their lands in the first place: occupation, closures, settler harassment, and so forth. In this sense, the Palestinian ties to the land are made illegible to the eyes of the state.

Beyond highlighting the particular scopic perspective embodied in the natural landscapes in Israel/Palestine, the use of aerial photos in this context demonstrates how the ideological properties of Israeli law are invisibilized precisely through that which is conspicuously visible. Finally, it demonstrates space's inherent imbrications with time.

\footnotetext{
${ }^{23}$ Suliman Shahin, Palestinian Israeli lawyer, Jerusalem Legal Aid and Human Rights Center (JLAC), interview, Jerusalem, December 23, 2005.

${ }^{24}$ Sandy Kedar, "Majority Time, Minority Time: Land, Nationality and Adverse Possession Laws in Israel," Iyuney Mishpat (Hebrew) 21(3) (1998), pp. 655-746.
} 
Seasons, periods of cultivation, originality and succession - all demonstrate the entanglement of space-time in this legal geography.

\section{Israel's Border Crossing: Seeing in Motion}

\section{A. Seeing in Motion}

The rich potentials that await anyone who wishes to mine the visual interconnections between law and geography are also illustrated in Israel's new border crossings ${ }^{25}$ The border is the official entry into (and, although less importantly here, also the official exit from) the nation-state, and, as such, it is monitored quite heavily. If the national landscaping project obscures law's visual components behind assumptions of objectivity and impartiality, at the border the project of visualization is practiced in the open and exercised to an extreme. Surveillance cameras, scanners, inspection booths, sensor machines, and searches are routine practices there. This heightened form of visualization is legitimized through what is viewed as the nature of this place: it is a liminal zone, a place "betwixt and between." ${ }^{.6}$ It is, one might even suggest, the state's ultimate site of seeing, the place where it most strongly and clearly defines its other.

Although movement (a nexus of matter and time) is an inevitable part of any project of seeing - and an important part of my work concerning natural landscapes - the border's visualization project is much more explicitly dynamic and thus temporal than are natural landscapes, which are conceived as inherently static and fixed, even as a

\footnotetext{
${ }^{25}$ Namely, the border regime between Israel and the occupied West Bank that has emerged in the last decade or so, and especially since 2002, when the construction of the Separation Wall had begun. For a detailed description of this project see Irus Braverman, "Civilized Borders: Dehumanizing Inspection at Israel's New Crossings," Antipode: A Radical Journal of Geography (forthcoming 2010).

${ }^{26}$ Victor W. Turner, "Betwixt and Between: The Liminal Period in Rites De Passage," in Reader in Comparative Religion: An Anthropological Approach eds. William A. Lessa and Evon Z. Vogt (4 ${ }^{\text {th }}$ Ed., Prentice Hall,1997), pp. 234-243.
} 
background to everyday life. At the border crossing, Israel's main physical concern is how to monitor and control moving targets, namely Palestinians who wish to enter Israel. This sort of monitoring is especially difficult because of the multiple interests involved: Israel's need to ensure a continuous flow of people for the routine procession of economic life, on the one hand, and its focus on security - namely, making sure that no illegal weapons or persons infiltrate its territories, on the other hand.

My work on this topic ${ }^{27}$ suggests that the project of surveillance at the Israeli border is increasingly built into the physical design of this place. This is part of a larger exploration of the recent changes at Israel's border on three fronts: mechanization, identification, and semi-privatization, or what I call civilization. On the mechanical front, I identify a series of fixtures positioned at the newly constructed Israeli border crossing: macro-fixtures such as the Wall and border crossings, alongside micro-fixtures such as signs, mechanical queues, and turnstiles. In addition to the architectural structure of the crossing, which is designed to tightly manage the physical movement of Palestinian users, more mobile features are also positioned at the border crossing, most visible of which are computers, biometric cards, scanners and sensors. The next section focuses on the work of visualization as it pertains to only one of these technologies: SafeView.

\section{B. SafeView}

In 2006, Israel spent some 50 million dollars on purchasing a series of sensors, developed by a United States based company. ${ }^{28}$ Electronically stripping the passenger down to his or her naked body, this technology replaces intimate physical contact with the ostensibly less intrusive act of seeing. Beyond being a source of information, the

\footnotetext{
${ }^{27}$ See Braverman, Civilized Borders.

${ }^{28}$ Yael Barda. "The Erotic Side of Occupation," Maarav 7, (2006), http://www.maarav.org.il/classes/PUItem.php?id=692\&lang=HEB (Hebrew, visited January 12, 2009).
} 
project of seeing into the body of the passenger establishes a physical and mental distance between the observed and the observer. This is performed in the name of safety and security. The nexus of vision and safety is reflected in the product's name: SafeView.

According to its manufacturer,

SafeView's patented technology detects objects composed of metal, ceramic, plastic, wood, or other materials that may be concealed. The technology was originally developed by a US Department of Energy lab, managed by Battelle Memorial Institute. One of its prime requirements was for it to be a totally safe technology for people and in particular to NOT use any form of ionizing (such as x-ray) radiation. The power density levels used by SafeView's portals are about 10,000 times less than a standard cell phone. SafeView's patented "active millimeter wave technology" is the safe, fast, and effective alternative to metal detectors, $\mathrm{x}$ ray machines, and pat down searches at security checkpoints. ${ }^{29}$

According to Colonel (retired) Dani Tirza, former Israeli architect of the Separation Barrier, "Instead of touching, [which is] humiliating... their purpose is to check the person and his luggage, without having to touch the person himself." ${ }^{30}$ Tirza believes, then, that by eliminating the need for intimate physical contact between Israeli border officials and Palestinian passengers (namely, frisks and vaginal or rectal searches), this new sensor's focus on seeing makes the required security checks conducted at the border more civilized, more humane.

\footnotetext{
${ }^{29}$ Letter from Richard L. Rowe, President \& CEO, SafeView, (Feb 21, 2006), at http://www.siliconbeat.com/entries/Safeview2.pdf (emphasis in original, visited January 22, 2009). Interestingly, this technology has also been used for cloth fitting and design. See at http://www.innovationamerica.org/archive.php?articleID=36, visited January 29, 2009).

${ }^{30}$ Colonel (retired) Dani Tirza, Head of Security Fence Operations 1994-2007, Israel Defense Forces, interview, Jerusalem, August 14, 2008;
} 


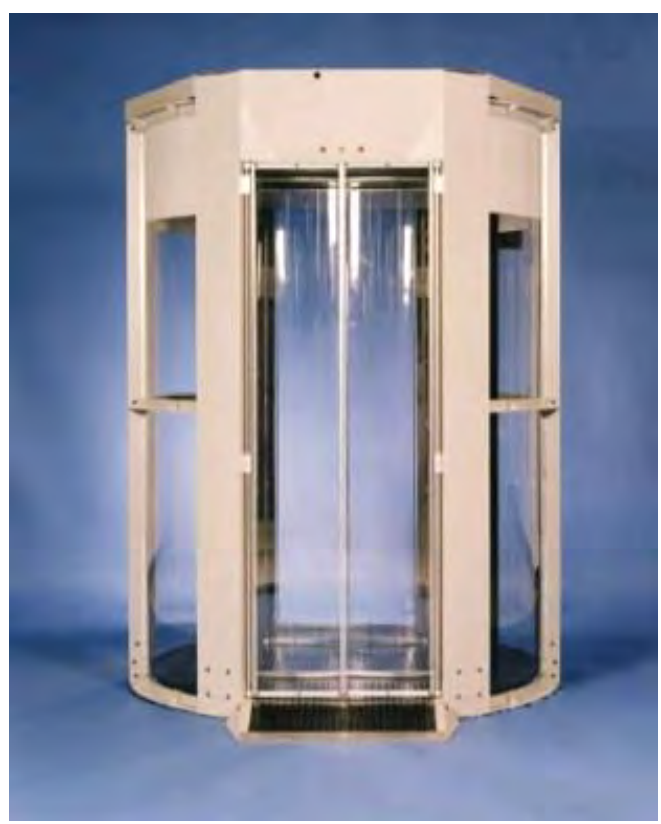

Figure 3: SafeView's Safescout 360 model $^{31}$

However, despite (or perhaps precisely because of) the manifest visibility of state surveillance at the space of the border, certain aspects are at the same time rendered invisible, as is well illustrated in the SafeView example. First, while pat-down searches involve a limited and known number of inspectors, the information recorded by the machine is available to an unknown, invisible, and thus even abstract gaze. Indeed, recorded by the machine, the Palestinian's bodily information is made visible not only to the inspector at the here-and-now of the border crossing, but also to an unlimited number of spectators in unknown spaces and temporalities. At the same time, border inspectors are the only lawful eyes of the state at this site. ${ }^{32}$ Only they are authorized to see into bodies at the border. This inner sight is, in other words, invisible to anyone but those legally authorized inspectors.

\footnotetext{
${ }^{31}$ From http://blogs.zdnet.com/emergingtech/?p=87 (visited January 29, 2009).

${ }^{32}$ This is not to say that theirs is the only gaze in this place. See Irus Braverman, "Checkpoint Gazes," in Engin Isin \& Greg Neilsen (eds.), Acts of Citizenship (Zed Publishers, 2008), pp. 211-214.
} 
Secondly, utilized at Israel's border as an alternative to tactile bodily searches, the project of mechanized seeing ends up hiding the very act of inspection. Whereas the intimacies of a one-on-one frisks practiced before the introduction of SafeView are usually considered humiliating, a visual inspection, even conducted electronically, is no less problematic. While unpleasant, the physical contact inherent in the invasive bodily search at the same time ensures that the person being searched is aware of the search. In other words, it is precisely the invasiveness of the physical search that has probably triggered the intense array of legal requirements that pertain to searches in a variety of modern jurisdictions around the world.

But since a passenger does not have a reasonable expectation of privacy at the border, it is not even clear if he or she are entitled to be made aware of a lawful search. "Why do we need his consent?" the Head of Israel's Crossing Administration asks me in an interview, "everything that has to do with obtaining permission wastes precious time," he concludes. ${ }^{33}$ In this sense, the very act of seeing by the state is rendered invisible through the legal distinction between private and public spaces. ${ }^{34}$

Thirdly and finally, the focus on seeing the body of the passenger in this riskphobic way reduces him or her to matter: flesh, organs, fluids, explosives. Here, it is the passenger's humanness that is made invisible.

\footnotetext{
${ }^{33}$ Bezalel Treiber, current Head of Minhelet Ha 'Maavarim or Crossing Administration, telephone interview (Buffalo-Jerusalem), Sept. 18, 2008.

${ }^{34}$ See similar discussions about surveillance cameras and the legal decisions that have legitimized its uses in public spaces in the United States. For example, Eugene Volokh, "Traffic Enforcement Cameras," Wall Street Journal, Mar. 26, 2002, p. A22.
} 


\section{Conclusion: Invisible Legal Geographies}

At this place and time, Legal Geography may benefit from a much stronger focus on embodied physical matters, and the embodied visuality inherent in legal projects in particular. To demonstrate the potential richness of such an inquiry, this article has focused on two sites of legal sight: first, the tree in the Israeli/Palestinian landscape and the project of seeing from a bird's eye view that occurs through the legal use of aerial photos at Israel's military legal proceedings; second, the Safeview machine at Israel's border crossings and the project of seeing in motion by state inspectors that occurs through Safeview technology.

In the first instance, the tree's legibility to the Cartesian eye of the state is what has made it into an important object of regulation and inspection by the state. Yet despite their enhanced legibility in the landscape, trees, and the project of greening the landscape at large, also serve to cover-up certain stories. I discussed the use of the aerial photograph in Israel's legal proceedings and mentioned certain perspectives that this technology leaves out of the picture. The project of seeing, I have thus defined, is simultaneously also a project of obscuring and, in this context, of rendering hidden the ideological places of law in this landscape.

Situated at the Israeli/Palestinian border, the second project discussed here engages even more explicitly with the visual powers of the state. Legitimized through its categorization as a liminal place, the Palestinian passenger that moves through the border is stripped from anything that may conceal his or her body (and that may be concealed by his or her body). In the name of law, he or she are made into objects of heightened visibility. However, seeing the Palestinian body through the sensor's scientific gaze also hides not only the level of bodily invasion practiced by the state but also the very 
occurrence of such an invasion as well as the passenger's very humaneness. The border inspection project is thus similar to the inspection of natural landscape by aerial photo experts in its disregard for the local story.

A few additional common themes can be drawn between these two examples. First, they are both an illustration of the immense power of vision - visibility and, at the same time, invisibility - in the intersections of law and geography. Secondly, both demonstrate that within the project of vision, the state practices a strong tendency toward a Cartesian perspective, one that highlights objectivity, scientificity, and detachment. Thirdly, these examples highlight the importance of the work of inspectors - human, and even more so, nonhuman - as intermediaries between law and territory, between law and matter. Moreover, the inspectors' view is not just a passive reflection on legal geographies but it is also an active making of these geographies. In this sense, they are geographers of law in the most literal sense. In other words, state law - as embodied in and practiced by the inspectors - not only takes physical matters and spatial arrangements into account but also contributes to their construction.

Fourthly and finally, my examples show the power of the hidden when simultaneously coupled with the visible: it is precisely because one does not associate war with trees that the natural landscape in Israel/Palestine has acquired such powers as a visible space that exists out there, beyond political struggles. And it is precisely because the border is seen as the place of Law that it can so well hide various legal projects. In both examples, legal arrangements appear natural or mechanical and thus as inevitable and even invisible. This, then, is law's double use of vision: first, law governs through the visibility of physical spaces; then, it uses this same conspicuous visibility to make its own ideological presence invisible. 
I have tried to problematize the project of seeing in the context of two spatiotemporal settings, identifying the need for a Legal Geography that pays more attention to the sensoral, and more specifically to the visual, properties of legal geographies. I will conclude by saying that much still remains to be seen. 